\title{
PENGEMBANGAN MODUL MATEMATIKA DENGAN PENDEKATAN KONTEKSTUAL PADA MATERI BANGUN DATAR UNTUK MAHASISWA PGSD UAD
}

\author{
Asih Mardati, M.Pd \\ PGSD FKIP Universitas Ahmad Dahlan \\ asihmardati@gmail.com
}

\begin{abstract}
ABSTRAK
Penelitian ini bertujuan untuk mengembangkan modul matematika dengan pendekatan kontekstual pada materi bangun datar untuk mahasiswa PGSD serta untuk mengetahui modul yang layak bagi mahasiswa PGSD. Jenis penelitian ini adalah penelitian dan pengembangan. Pengembangan dilakukan mengacu pada model pengembangan ADDIE. Subbjek uji coba penelitian adalah mahasiswa PGSD UAD angkatan 2015. Hasil penilaian ahli materi dan pembelajaran diperoleh skor $\mathrm{X}=259$ menunjukkan modul matematika dengan pendekatan kontekstual pada materi bangun datar layak digunakan dengan kriteria "Sangat Baik". Hasil penilaian ahli media diperoleh skor $\mathrm{X}=161$ menunjukkan modul matematika dengan pendekatan kontekstual pada materi bangun datar layak digunakan dengan kriteria "Sangat Baik".
\end{abstract}

Kata kunci: Pengembangan Modul Matematika, Kontekstual, Bangun Datar

\section{PENDAHULUAN}

Pembelajaran matematika merupakan salah satu matakuliah yang harus ditempuh mahasiswa jurusan Pendidikan Guru Sekolah Dasar (PGSD). Matakuliah ini sebagai ilmu yang seharusnya dipahami dan dikuasai bagi calon guru SD disamping bidang studi lain yaitu Bahasa Indonesia, Ilmu Pengetahuan Alam, Ilmu Pengetahuan Sosial, Kewarganegaraan. Matematika ilmu dasar berhitung bagi siswa di SD dasar, sehingga calon guru SD sudah seharusnya menguasai terebih dahulu menguasai dan memahami ilmu matematika dasar sebelum mereka mengajarkan matematika kepada siswanya. Namun, dalam proses perkuliahan tahun ajaran 2015/2016 banyak mahasiswa PSGD yang belum menguasai konsep matematika dasar dengan baik terutama pada materi bangun datar. Hal ini dapat ditunjukkan ketika proses pembelajaran sedang berlangsung mahasiswa banyak yang tidak menguasai konsep bangun datar. Mereka mengetahui rumus-rumus pada bangun datar tetapi tidak paham cara menemukan rumus tersebut dan bagaimana penerapannya dalam kehidupan sehari-hari. Materi bangun datar harus dikuasai dengan baik, karena sebagai syarat untuk mempelajari materi selanjutnya yaitu bangun ruang.

Sebagai pendidik maupun calon pendidik sudah seharusnya mengembangkan bahan ajar yang dapat membantu peserta didik memahami suatu konsep dan melengkapi sumber belajar bagi peserta didik. Dalam Peraturan Pemerintah nomor 19 tahun 2005 Pasal 20, diisyaratkan bahwa pendidik diharapkan mengembangkan materi pembelajaran, yang kemudian dipertegas melalui Peraturan Menteri Pendidikan Nasional (Permendiknas) nomor 41 tahun 2007 tentang Standar Proses, yang antara lain mengatur tentang perencanaan proses pembelajaran yang mensyaratkan bagi pendidik pada satuan pendidikan untuk mengembangkan rencana pelaksanaan pembelajaran (RPP). Salah satu elemen dalam RPP adalah sumber belajar. Dengan demikian, pendidik diharapkan mampu 
mengembangkan bahan ajar sebagai salah satu sumber belajar. Sumber belajar yang dikembangkan berbentuk modul matematika dengan pendekatan kontekstual. Modul merupakan seperangkat bahan ajar cetak yang disajikan secara sistematis. Ada tiga pengertian modul menurut Depdiknas (2008: 30) yaitu: 1) suatu unit bahan yang dirancang secara khusus sehingga dipelajari oleh pelajar secara mandiri; 2) merupakan program pembelajaran yang utuh, disusun secara sistematis, mengacu pada tujuan pembelajaran yang jelas dan terukur; dan 3) memuat tujuan pembelajaran, bahan dan kegiatan untuk mencapai tujuan serta evaluasi terhadap pencapaian tujuan pembelajaran.

Dharma (2008: 5) menjelaskan bahwa penulisan modul memiliki tujuan yaitu 1) memperjelas dan mempermudah penyajian pesan agar tidak terlalu bersifat verbal; 2) mengatasi keterbatasan waktu, ruang, dan daya indera, baik peserta belajar maupun guru/ instruktur; 3) dapat digunakan secara tepat dan bervariasi, seperti untuk meningkatkan motivasi dan gairah belajar; mengembangkan kemampuan dalam berinteraksi langsung dengan lingkungan dan sumber belajar lainnya yang memungkinkan peserta didik belajar mandiri sesuai kemampuan dan minatnya.Penerapan modul dengan pendekatan kontekstual ini sebagai salah satu cara agar peserta didik mudah dalam memahami suatu konsep. Hal tersebut sejalan dengan hasil penelitian yang dilakukan Novia Prastika, dkk tahun 2013 yang berjudul pengaruh pendekatan kontekstual terhadap pemahaman konsep matematis. Hasil penelitian menunjukkan bahwa dengan pendekatan kontekstual dapat membantu siswa lebih memahami konsep matematika.

Pembelajaran dengan pendekatan kontekstual berarti mengaitkan pembelajaran dengan pengetahuan awal yang telah dimiliki, mengaitkan pembelajaran dengan situasi lingkungan peserta didik dan memotivasi peserta didik dengan menyediakan kegiatan matematika dan tugas-tugas matematika yang berhubungan dengan kehidupan sehari-hari terutama materi bangun datar.Pendekatan kontekstual memiliki tujuh komponen utama (Nurhadi, 2002: 10), yaitu: 1) Kontruktivisme; 2)Menemukan; 3) Bertanya; 4) Masyarakat belajar; 5) Pemodelan; 6) Refleksi dan 7) Penilaian yang sebenarnya.

Modul merupakan bahan ajar yang dapat digunakan sebagai pengganti guru atau pendidik ketika di rumah. Oleh karena itu, modul harus bisa membantu siswa memahami suatu konsep tanpa harus didampingi oleh pendidiknya. Kompetensi pada bangun datar sering dijumpai dalam kehidupan sehari-hari tanpa disadari, seperti mengukur luas suatu bangunan, membuat meja dengan konstruksi bentuk bangun-bangun datar, dan lain sebagainya. Oleh karena itu, konsep bangun datar harus benar-benar dipahami peserta didik dengan baik, terutama saat mereka sudah menjadi seorang guru mereka akan menjelaskan materi ini. Untuk memberikan pemahaman siswa SD tidaklah mudah, sebelum mengajarkan ke siswanya calon guru harus terlebih dahulu memahami konsep bangun datar ini. Modul berbasis kontekstual ini mengarahkan peserta didik menemukan konsep dengan tugas-tugas yang diberikan berdasarkan kondisi yang sering dijumpai dalam kehidupan di dunia nyata atau kehidupan sehari-hari. Dalam penyusunan materi pada modul yang dikembangkan harus disesuaikan dengan karakteristik secara umum dari peserta didik. Tujuan akhir dikembangkan modul ini adalah untuk mempermudah calon pendidik dalam memami konsep bangun datar ketika menjelaskan kepada peserta didiknya yaitu anak usia SD.

Anak usia SD termasuk dalam tahap operasional konkret. Menurut Piaget (Santrock, 2009, 55) bahwa pemikiran operasional konkret mencakup penggunaan operasi, sehingga mereka masih memerlukan hadirnya media maupun bahan ajar sebagai alat pendukung dalam 
pembelajaran.Bahan ajar dapat digunakan sebagai pendukung proses pembelajaran. Materi bangun datar di Sekolah Dasar mulai diajarkan dari kelas rendah. Oleh karena itu, penyusunan materi pada modul yang dikembangkan terdapat gambargambar pendukung untuk mempermudah dalam memahami konsep. Gambar-gambar tersebut diambil dari lingkungan sekitar sehingga peserta didik dapat melihat langsung contoh dalam kehidupan seharihari atau konkret. Disamping itu, dalam modul yang dikembangkan dihadirkan berbagai permasalahan bangun datar yang diambil dari kehidupan sehari-hari atau lingkungan sekitar sehingga jelas tampak penggunaan konsep bangun datar tersebut. Dengan menggunakan gambar yang konkret maupun permasalahan yang konkret peserta didik lebih cepat memahami konsep yangdisampaikan. Sejalan dengan perkembangan kognitif seseorang menurut Bruner (Liao, 2012, 185) terjadi melalui tiga tahap yaitu tahap enaktif, tahap ikonik, dan tahap simbolik. Memasukkan unsur gambar maupun permasalahan konkret pada modul termasuk pada tahap ikonik yaitu tahap anak-anak telah tumbuh, dapatmenggunakan imajinasi, gambar, atau ikon untuk memahami dunia dan menggunakannya untuk membantu mereka berpikir.

\section{METODE PENELITIAN}

Model Pengembangan

Jenis penelitian ini adalah penelitian dan pengembangan atau Research and Developement ( $\mathrm{R} \& \mathrm{D})$. Pengembangan dilakukan mengacu pada model pengembangan ADDIE(Benny A. Pribadi, 2009:127)yang terdiri dari Analysis (Analisis), Design (Perencanaan), Development (Pengembangan), Implementation (Implementasi) dan Evaluation (Evaluasi).

\section{Desain Uji Coba Produk}

Uji coba yang dilakukan bertujuan untuk menyempurnakan modul matematika yang dikembangkan dengan pendekatan kontekstual pada materi bangun datar untuk mahasiswa PGSD dan untuk mengetahui kepraktisan penggunaan modul matematika yang dikembangkan. Uji coba yang dilakukan meliputi dua tahap, yaitu uji coba satu-satu dan uji coba kelompok kecil.

\section{Subjek Penelitian}

Subjek coba dalam penelitian dan pengembangan ini adalah sebagai berikut: uji coba satu-satu subjeknya dua orang ahli materi dan pembelajaran yang berkompeten dan dua orang ahli media yang berkompeten. Sedangkan uji coba kelompok kecil terhadap kepraktisan penggunaan modul matematika dilakukan terhadap 10 orang mahasiswa PGSD.

Teknik dan Instrumen Pengumpulan Data

Teknik pengumpulan data yang digunakan dalam penelitian dan pengembangan ini antara lain penilaian ahli, observasi dan dokumentasi. Lembar penilaian ahli yang berupa angket expert bertujuan untuk menilai kelayakan produk yang dikembangkan. Penilaian produk ini dilakukan oleh ahli materi dan pembelajaran serta ahli media. Sedangkan observasi dilakukan untuk memperoleh data atau informasi terkait dengan proses pelaksanaan penggunaan modul matematika dengan pendekatan kontekstual pada materi bangun datar.

Instrumen pengumpulan data pada penelitian ini digunakan untuk mengumpulkan data pada tahap uji coba satu-satu maupun uji coba kelompok kecil. Instrumen yang digunakan dalam penelitian dan pengembangan ini adalah lembar penilaian kelayakan materi dan pembelajaran, lembar penilaian kelayakan ahli media, serta lembar observasi mahasiswa.

\section{Teknik Analisis Data}

Data yang diperoleh melalui lembar penilaian produk dianalisis secara 
kuantitatif dan uraikan secara kualitatif dan lembar observasi mahasiswa terhadap penggunaan modul matematika dianalisis secara statistik kualitatif dan kuantitatif. Data kualitatif dalam penelitian dan pengembangan ini diperoleh dari: 1) data proses pengembangan modul; 2) komentar dan saran yang diperoleh dari ahli media, ahli materi dan pembelajaran; 3) komentar dan saran dari mahasiswa. Data yang diperoleh dianalisis dan dideskripsikan secara kualitatif untuk merevisi produk yang dikembangkan.

Data kuantitatif dalam penelitian dan pengembangan berupa: 1) skor penilaian oleh ahli media, dan 2) skor ahli materi dan pembelajaran. Data kuantitatif dianalisis dengan teknik sebagai berikut: (a) tabulasi semua data yang diperoleh, (b) menghitung skor total dan rerata skor dari setiap komponen, (c) mengubah rerata skor menjadi nilai dengan kriteria.Menurut Widyoko $(2013,238)$ skor yang diperoleh kemudian dikonversikan menjadi kriteria dengan acuan Tabel 1 berikut.

Tabel 1. Konversi Interval Rerata Skor Menjadi Kriteria

\begin{tabular}{lcc}
\hline No & $\begin{array}{c}\text { Rentang skor }(i) \\
\text { kuantitatif }\end{array}$ & Kriteria kualitatif \\
\hline 1. & $X>\left(\bar{X}_{i}+1,8 \mathrm{sb} i\right)$ & Sangat baik \\
2. & $\left(\bar{X}_{i}+0,6 \mathrm{sb} i\right)<X \leq$ & Baik \\
& $\left(\bar{X}_{i}+1,8 \mathrm{sb} i\right)$ & \\
3. & $\left(\bar{X}_{i}-0,6 \mathrm{sb} i\right)<X \leq$ & \\
& $\left(\bar{X}_{i}+0,6 \mathrm{sb} i\right)$ & Cukup baik \\
4. & $\left(\bar{X}_{i}-1,8 \mathrm{sb} i\right)<X \leq$ & \\
& $\left(\bar{X}_{i}-0,6 \mathrm{sb} i\right)$ & Kurang baik \\
5. & $X \leq\left(\bar{X}_{i}-1,8 \mathrm{sb} i\right)$ & $\begin{array}{c}\text { Sangat kurang } \\
\text { baik }\end{array}$ \\
\hline
\end{tabular}

Keterangan:

$\bar{X}_{i}=\frac{1}{2}$ (skor maksimum +skor minimum) $\mathrm{sb}_{\mathrm{i}}=\frac{1}{6}$ (skor maksimum - skor minimum $)$ $X=$ skor yang diperoleh

Hasil data observasi yang dilakukan peneliti akan dianalisis dengan mengkonversi rata-rata yang diperoleh menjadi nilai kualitatif sesuai kriteria kepraktisan Soewandi (2005: 50) dalam Tabel 2 berikut.

Tabel 2.Kriteria Kepraktisan Berdasarkan Observasi Pembelajaran

\begin{tabular}{cc}
\hline$\%$ Keterlibatan & Kepraktisan \\
\hline $0 \leq \mathrm{n} \leq 21$ & Tidak Praktis \\
$21 \leq \mathrm{n} \leq 41$ & Kurang praktis \\
$41 \leq \mathrm{n} \leq 61$ & Cukup praktis \\
$61 \leq \mathrm{n} \leq 81$ & Praktis \\
$81 \leq \mathrm{n} \leq 100$ & Sangat praktis \\
\hline
\end{tabular}

Keterangan:

$n=$ proses pembelajaran dengan Media

$n=\frac{n_{1}}{n_{2}} \times 100 \%$

$n_{1}=$ skor yang diperoleh

$n_{2}=$ skor maksimal

Dalam penelitian ini ditetapkan nilai kelayakan produk minimal "B" kategori "Baik". Dengan demikian, hasil penilaian ahli materi dan pembelajaran, serta ahli media jika memberi hasil akhir minimal "B" atau "Baik", maka produk pengembangan layak digunakan sebagai media pembelajaran. Namun, jika hasil analisis data yang tidak memenuhi kategori "Baik" pada penelitian ini akan dijadikan bahan pertimbangan untuk merevisi perangkat pembelajaran sebelum diujicobakan.Sedangkan kriteria kepraktisan penggunaan modul dalam proses pembelajaran dikatakan memiliki kepraktisan yang baik, jika minimal tingkat kepraktisan yang dicapai adalah praktis.

\section{Hasil Penelitian dan Pembahasan}

Pengembangan modul matematika dengan pendekatan kontekstual pada materi bangun datar ini dilakukan dengan metode 
research and development (R\&D). Model pengembangan yang digunakan adalah ADDIE. Berikut ini dijelaskan langkah yang dilakukan masing-masing tahapan beserta hasilnya.

Tahap analyze atau analisis dilakukan pengamatan dan pencermatan terhadap kompetensi yang akan dicapai pada materi bangun datar yang akan dikembangkan pada modul terlebih dahulu. Analisis yang dilakukan meliputi analisis kompetensi yang akan dicapai, analisis karakteristik mahasiswa PGSD, serta analsis referensi yang akan digunakan sebagai acuan dalam penyusunan bahan ajar. Dalam tahapan ini dikembangan indikator capaian setiap materi pada bangun datar. Hal ini bertujuan untuk mengukur tingkat kedalaman materi yang bertumpu pada kurikulum matematika dasar untuk mahasiswa PGSD. Dari tahapan ini diperoleh hasil untuk materi pokok bangun datar pada mata kuliah Matematika Dasar untuk mahasiswa PGSD yaitu Mengenal titik, garis, bidang dan sudut; Segitiga, Segiempat, dan Segibanyak. Hasil analisis tujuan pembelajaran meliputi capaian pengetahuan, capaian sikap, dan capaian keterampilan.

Selanjutnya dilakukan analisis terhadap karakteristik peserta didik dalam hal ini disebut dengan mahasiswa. Pada langkah ini dilakukan pengamatan secara langsung ketika proses pembelajaran. Berdasarkan hasil pengamatan ketika pembelajaran di kelas pada bulan Mei 2016, diketahui bahwa sebagian besar mahasiswa belum menguasai konsep matematika, serta mahasiswa belum bisa belajar secara mandiri karena keterbatasan referensi matematika yang khusus untuk PGSD. Dengan adanya bahan ajar yang dikembangkan yaitu berupa modul diharapkan dapat membantu mahasiswa dalam memahami konsep matematika terutama bangu datar sebagai dasar dalam mempelajari bangun ruang. Bangun datar harus dikuasi dengan baik oleh mahasiswa karena materi pengantar dalam mempelajari materi selanjutnya yaitu bangun ruang. Selain analisis tujuan pembelajaran dan karakteristik mahasiswa, dilakukan analisis terhadap sumber yang akan digunakan sebagai acuan atau referensi dalam penyusunan modul.

Kegiatan yang dilakukan pada tahap design atau perencanaan pengembangan modul bangun datar dengan pendekatan kontekstual meliputi penyusunan draf awal modul dan penyusunan instrumen yang digunakan. Proses penyusunan draf awal modul dilakukan dengan menentukan kompetensi yang akan dicapai, kemudian menentukan judul setiap bab maupun subbab.Setelah draf awal produk selesai disusun, selnjutnya peneliti mengembangakan instrumen yang digunakan untuk evaluasi produk. Instrumen yang digunakan antara laian yaitu lembar penilaian ahli materi dan pembelajaran, lembar penilaian ahli media, serta lembar penilaian aktivitas penggunaan modul untuk pengguna atau mahasiswa. Kisi-kisi instrumen yang dikembangkan mengacu pada kajian teori yang ada serta sesuai dengan kebutuhan data yang akan diperoleh peneliti. Aspek yang dinilai oleh ahli materi dan pembelajaran terdiri dari aspek kelayakan isi, kebahasaan, sajian, dan pendekatan kontekstual. Sedangkan untuk penilaian ahli media aspek yang dinilai terdiri dari aspek bahan ajar modul, gambar dan tampilan.

Setelah dilakukan tahap pengembangan maka produk yang dikembangkan diujicobakan dalam kelompok kecil. Uji coba penggunan produk yang dikembangkan dilakukan terhadap 10 mahasiswa PGSD UAD. Dalam memilih mahasiswa untuk uji coba dipilih secara representatif dan dipertimbangkan agar semua kelompok terwakili mahasiswa yang berkemampuan tinggi, sedang dan rendah. Pada saat uji coba mahasiswa diberikan produk untuk dipelajari. Namun, sebelumnya diberikan penjelasan terhadap bagian modul dan 
petunjuk dalam penggunaan modul tersebut.

Tahap terakhir dari model pengembangan ADDIE adalah tahap evaluasi. Evaluasi yang dilakukan terhadap bahan ajar berupa modul yang dikembangkan dengan pendekatan kontekstual meliputi evaluasi hasil penilaian ahli materi dan pembelajaran, serta evaluasi hasil penilaian ahli media. Hasil penilaian dari ahli digunakan untuk perbaikan modul sehingga menjadi modul yang layak digunakan bagi mahasiswa sebagai salah satu referensi atau sember belajar.

Data hasil uji coba produk diperoleh dari berbagai sumber melalui lembar penilaian ahli materi dan pembelajaran, ahli media, dan uji coba terhadap 10 mahasiswa. Uji coba hanya dilakukan kepada kelompok kecil karena keterbatasan waktu.

Hasil Penilaian Ahli Materi dan Pembelajaran. Draf produk yang telah selesai disusun dilakukan penilaian oleh 2 orang teman sejawat sebagai ahli materi dan pembelajaran dengan latar belakang pendidikan S2 matematika atau S2 Pendidikan Matematika.Aspek penilaian yang diajukan pada ahli materi meliputi aspek kelayakan isi, aspek kebahasaan, aspek sajian dan aspek pendekatan kontekstual. Data hasil penilaian 2 orang ahli materi dan pembelajaran secara keseluruhan diperoleh skor maksimalnya 300 , skor minimumnya $60, \bar{X}_{i}=180$, dan $\mathrm{sb}_{\mathrm{i}}=40$.Berdasarkan keseluruhan penilaian produk oleh ahli materi dan pembelajarandiperoleh skor $\mathrm{X}=259$, yang termasuk dalam kriteria nilai "Sangat Baik".

Hasil Penilaian Ahli Media. Draf produk yang telah selesai disusun dilakukan penilaian oleh 2 orang teman sejawat sebagai ahli media.Aspek penilaian yang diajukan pada ahli media meliputi aspek bahan ajar modul, aspek gambar, dan aspek tampilan. Data hasil penilaian 2 orang ahli media secara keseluruhan diperoleh skor maksimalnya 190, skor minimumnya $38, \bar{X}_{i}=114$, dan $\mathrm{sb}_{\mathrm{i}}=25,33$.Berdasarkan keseluruhan penilaian produk oleh ahli media diperoleh skor $X=161$, yang termasuk dalam kriteria nilai "Sangat Baik".

Hasil Penilaian penggunaan modul oleh mahasiswa. Berdasarkan penilaian 10 mahasiswa diperoleh hasil $n=92,85 \%$ dengan kriteria penggunaan modul sangat praktis.

\section{KESIMPULAN DAN SARAN}

\section{Kesimpulan}

Berdasarkan hasil penelitian dan pembahasan maka dapat diambil kesimpulan sebagai berikut:

1. Pengembangan bahan ajar berbentuk modul pada materi bangun datar dengan pendekatan kontekstual untuk mahasiswa PGSD disusun dengan menerapkan model pengembangan ADDIE (Analysis, Design, Development, Implementation, \& Evaluation). Langkah analisis meliputi analisis kurikulum, analisis karakteristik siswa dan analisis instruksional.Tahap perancangan dilaksanakan dengan penyusunan modul. Pada tahap pengembangan dilaksanakan pengembangan draf modul dengan aspek-aspek yang telah ditentukan, dilanjutkan dengan validasi ahli. Hasil validasi dari ahli media maupun ahli materi dan pembelajaran menunjukkan tingkat kelayakan yang sangat baik dan modul tersebut dapat diujicobakan dengan revisi. Uji coba dilakukan terhadap 10 mahasiswa yang dipilih secara acak. Bedasarkan hasil penialain mahasiswa dalmpenggunaan modul diperoleh hasil bahwa proses pembelajaran dengan menggunakan 
modul termasuk dalam kriteria sangat praktis digunakan.

2. Berdasarkan keseluruhan penilaian produk oleh ahli materi dan pembelajarandiperoleh skor $\mathrm{X}=259$, yang termasuk dalam kriteria nilai "Sangat Baik". Sedangkan keseluruhan penilaian produk oleh ahli media diperoleh skor $X=161$, yang termasuk dalam kriteria nilai "Sangat Baik". Dari hasil penilaian tersebut maka modul yang dikembangkan dengan pendekatan kontekstual dinyatakan layak uji coba kelompok kecil dengan revisi.

\section{Saran}

Adapun saran yang dapat disampaikan berdasarkan hasil penelitian ini dalam rangka mengembangkan bahan ajar khususnya modul adalah Modul yang dihasilkan dalam penelitian ini dapat digunakan sebagai bahan ajar mahasiswa PGSD ketika kuliah Matematika Lanjut.

\section{DAFTAR PUSTAKA}

Benny A. Pribadi. 2009. Model Desain Sistem Pembelajaran. Jakarta: Dian Rakyat

Dharma, Surya. 2008. Penulisan Modul. Jakarta: Depdiknas
Depdiknas. (2008). Panduan pengembangan bahan ajar. Jakarta:Direktorat Jenderal Manajemen Pendidikan Dasar dan Menengah.

Liao, S.Y. (2012). The application of piaget and bruner's cognitivedevelopmentaltheory in children's dance teaching. The International Journal of ArtEducation, 10 (2). 185-186.

Novia Prastika, dkk. 2013. Pengaruh pendekatan kontekstual terhadap pemahaman konsep matematis.

Nurhadi. 2002. Pendekatan Kontekstual. Jakarta: Depdiknas

Permendiknas No 41 Tahun 2007 tentang Standar Proses Untuk Satuan Pendidikan Dasar dan Menengah

Santrock, J.W. (2009). Psikologi pendidikan. Educational psychology EdisiKetiga Buku I (Terjemahan Diana Angelica). New York: McGraw-Hill.(Buku asli diterbitkan tahun 2008)

Soewandi, Slamet. 2005. Perspektif Pembelajaran di Berbagai Bidang. Yogyakarta: USD

Widiyoko, Eko Putro. 2009. Evaluasi Program Pembelajaran Panduan Praktis Bagi Pendidik dan Calon Pendidik. Yogyakarta: Pustaka Belajar 